\title{
HIV Knowledge and Awareness Status of the Medical Students in Romania: An Awareness Study
}

Florida Parcaoglu ${ }^{1}$ and Habip Gedik ${ }^{2 *}$

${ }^{1}$ School of Medicine, Grigore T. Popa University of Medicine and Pharmacy Strada Universității 16, lași, Romanya

${ }^{2}$ Department of Infectious Diseases and Clinical Microbiology, Ministry of Health Bakırköy Sadi Konuk Training and Research Hospital, Istanbul, Türkiye

\section{Abstract}

Objective: We aimed to evaluate the status of knowledge and attitudes of medical students about HIV/ AIDS.

Material and methods: In this descriptive, cross-sectional survey study, the status of knowledge and attitudes of medical students of Grigore T. Popa University of Medicine and Pharmacy about HIVIAIDS in June 2017 were evaluated.

Results: A total of 85 medical students answered all of our 19 survey questions. The mean age was $21.80 \pm 1.37$ years (Range: 19-24 years). In the second question, six out of the 15 choices were correct and the mean of correct answers was $4.41 \pm 1.49$. There was a significant relationship between the grade of the students and the level of knowledge in the responses to the seventh question ( $p: 0.024)$.

Conclusion: It is obvious that there are needed more health- informative organizations targeting the young population especially at schools and universities about sexually transmitted diseases, especially HIVIAIDS transmission routes, misconceptions about HIV, preventive measures, and the life expectancy after HIV acquirement. Those programs may raise the HIV awareness and be useful to change the behaviour against HIV patients eliminating stigma.

Keywords: HIV; AIDS; Awareness; Students; Medical faculty; Attitude; Romania

\section{Introduction}

Human immunodeficiency virus (HIV) has been causing one of the devastating pandemics and has a great impact on society due to its history of evolution. Acquired immunodeficiency syndrome (AIDS) was publicly reported in 1981 by the Centres for Disease Control (CDC) in the USA. Doctors reported the unexpected clusters of extremely rare diseases, such as Pneumocytis carinii pneumonia and Kaposi's sarcoma. Those conditions manifested in a defined risk group, such as young homosexual men. After a short time, the disease had been recognized in other groups, including hemophiliacs, blood transfusion recipients, and intravenous drug users. By 1982, cases were being seen among the partners and infants of those infected with HIV [1,2]. HIV is transmitted by contact with an infected persons' certain body fluids, such as blood, semen, pre-seminal fluid, rectal fluids, vaginal fluids, breast milk and by sharing needles/syringes (primarily for drug injection), and rarely through the transfusions of infected blood [3].

The World Health Organization (WHO) and the Joint United Nations Program on HIV and AIDS (UNAIDS) reported that 36.7 million people were living with HIV globally; 2.1 million people became newly infected, and 1.1 million people died of HIV related causes at the end of 201 [4]. The first HIV case was reported in Romania in 1985. Of 18,797 HIV/AIDS cases registered between 1985 and 2013, $55 \%$ were male [5]. The rates of new cases with HIV increased $17.9 \%$; 47.3\% between 2009 and 2010; and 20.3\% between 2011 and 2012 [6,7]. According to the report of Romanian Ministry of Health, National Institute for Infectious Diseases "Prof. Dr. Matei Bals" Compartment for Monitoring and Evaluation of HIV/AIDS Data 2012, the number of HIV cases was 416 in the age group 1-19 years, while it was 4813 in the age group 20-24 years [7]. The age group 20-24 years is generally the college students at high risk for the sexually transmitted diseases due to the risky attitudes in their sexually active lives.

The studies, which were conducted in different countries regarding awareness of HIV/AIDS among college students, have reported that students had insufficient knowledge about HIV prevention, the protection against HIV, and transmission routes of HIV [8-11]. Throughout the world, young people are the highest risk group. Their awareness and knowledge on the transmission routes and prevention of HIV/AIDS is very important. It was reported that the HIV awareness programs had a significant impact on the community [12]. Medical students are also trained about all HIV during their education, so their knowledge about HIV should be at the top level to inform their circles and the community. For that reason, we aimed to evaluate the level of knowledge and attitudes of medical students about HIV and AIDS.

\section{Material and Methods}

The purpose of this descriptive, cross-sectional survey was to evaluate the knowledge and perceptions of the medical students of Grigore T. Popa University of Medicine and Pharmacy, Iasi, Romania about HIV and AIDS. The samples were not selected for the survey study, and the survey was applied to students that agreed to participate in June 2017 at Grigore T. Popa University of Medicine. The characteristics of the students included gender, age, and grade in the faculty. The duration of training is six years in the medical faculty, so students were categorized into six grades. There was no question about the identity of the participant.

*Corresponding author: Gedik H, Department of Infectious Diseases and Clinical Microbiology, Ministry of Health Bakırköy Sadi Konuk Training and Research Hospital, İstanbul, Turkey, Tel: +90 21241453 09; E-mail: habipgedik@yahoo.com

Received: August 03, 2017; Accepted: August 07, 2017; Published: August 14 2017

Citation: Parcaoglu F, Gedik H (2017) HIV Knowledge and Awareness Status of the Medical Faculty Students in Romania: An Awareness Study. J Infect Dis Med 2: 111. doi: $10.4172 / 2576-1420.1000111$

Copyright: @ 2017 Parcaoglu F, et al. This is an open-access article distributed under the terms of the Creative Commons Attribution License, which permits unrestricted use, distribution, and reproduction in any medium, provided the original author and source are credited. 
The questionnaire was written in English. The structured questionnaire included 19 questions. Students were asked to choose single answer, multiple answers, or yes/no in the questionnaire. The questions were about HIV definition, early sign and symptoms, modes of transmission, attitudes, and perceptions towards HIV positive patients, prevention measures, detection of disease, and counselling choices.

\section{Statistics}

Data are analysed using SPSS 23.0 (Chicago, IL, USA). Continuous variables were described as mean \pm standard deviation and range. Percentile values were described with decimals. Dichotomous variables were compared by Fisher's exact test for two by two comparisons or Pearson $\chi^{2}$ for greater than two responses. P-value $<0.05$ was considered as significant. The $\mathrm{P}_{1}$ indicates the statistical comparison of the responses between men and women. The $\mathrm{P}_{2}$ indicates the statistical comparison of the responses by the grades of the students.

\section{Results}

A total of 85 medical students, who comprised of 46 females and 39 males, answered all of our 19 survey questions. The mean age was 21.80 \pm 1.37 years (Range: $19-24$ years). The numbers of students with the grades of medical faculty were four $(4.7 \%)$ in $1^{\text {st }}$ grade, $12(14.1 \%)$ in $2^{\text {nd }}$ grade, $23(27.1 \%)$ in $3^{\text {rd }}$ grade, $10(11.8 \%)$ in $4^{\text {th }}$ grade, $30(35.3 \%)$ in $5^{\text {th }}$ grade, $6(7.1 \%)$ in $6^{\text {th }}$ grade.

The questions and responses of the students have been revealed in Table 1 . On the second question, six out of the 15 choices were correct and the mean of correct answers was $4.41 \pm 1.49$ (Range: 1-6). There was a significant relationship between the grade of the students and the level of knowledge in the responses to the seventh question (p: 0.024). Since the fourth and fifth graders had more knowledge about HIV than those in other grades. There was found a significant relationship between choosing the correct answer and the grades of the students in the eighth question about the protection of the contraceptive pill against HIV (p: 0.0005). The high rates of wrong answers $(26 \%)$ of fifth graders caused that significant relationship. There was found a significant relationship between the correct response and the grade of the students in the $17^{\text {th }}$ question about HIV prevention (p: 0.001). The numbers of wrong answers were higher in the first and second graders, and the fact that nearly half of the students in third grade responded false caused a significant difference.

\section{Discussion}

College students are one of the groups at higher risk of HIV infection, and some of them due to the lack of proper knowledge regarding the disease due to lack of knowledge and training at educational institutes [13]. HIV awareness should be kept at a higher level, as they may instruct people about HIV during their social contact. In this study, the majority of students demonstrated a sufficient knowledge about HIV transmission routes, risky behaviours, and HIV prevention. However, there are still some misconceptions needed to be corrected among students [13].

Our study findings indicated that medical doctors and medical centers are commonly preferred to receive information about HIV/ AIDS, followed by the Internet. Preparing brochures and the training programs about HIV and other sexually transmitted diseases are performed at hospitals and community health centers may be useful to instruct students and people. Since people commonly hesitate to ask

\begin{tabular}{|c|c|c|c|c|c|}
\hline Questions & & $\mathbf{n}$ & $\%$ & P1 & $\mathbf{P 2}$ \\
\hline \multirow{2}{*}{$\begin{array}{l}\text { 1. HIV stands for Human } \\
\text { Immunodeficiency Virus }\end{array}$} & Correct & 82 & $96.50 \%$ & & \\
\hline & FALSE & 3 & $3.50 \%$ & & \\
\hline \multirow{14}{*}{ 2. HIV can be transmitted by } & Coughing and sneezing & 3 & $3.50 \%$ & & \\
\hline & Sharing glass with someone & 3 & $3.50 \%$ & & \\
\hline & Sexual Intercourse & 81 & $95.30 \%$ & & \\
\hline & Sharing toilet seats with an infected person & 5 & $5.90 \%$ & & \\
\hline & Mosquito bite & 12 & $14.10 \%$ & & \\
\hline & Blood & 82 & $96.50 \%$ & & \\
\hline & Semen & 56 & $65.90 \%$ & & \\
\hline & Vaginal fluids \& rectal fluids & 68 & $80 \%$ & & \\
\hline & Saliva, urine, sweat & 11 & $12.90 \%$ & & \\
\hline & breast milk & 41 & $48.20 \%$ & & \\
\hline & Hugging and kissing with an infected person & 4 & $4.70 \%$ & & \\
\hline & Sharing razor blades & 47 & $55.30 \%$ & & \\
\hline & Sharing towels & 2 & $2.40 \%$ & & \\
\hline & Mouth to mouth resuscitation & 8 & $9.40 \%$ & & \\
\hline \multirow{6}{*}{$\begin{array}{l}\text { 3. Choose the wrong answer regarding } \\
\text { AIDS }\end{array}$} & AIDS and HIV refer to same thing, a virus. & 25 & $29.40 \%$ & & \\
\hline & AIDS stands for Acquired Immunodeficiency Syndrome & & & & \\
\hline & AIDS is a stage of HIV infection & 60 & $70.60 \%$ & & \\
\hline & HIV leads to AIDS & & & & \\
\hline & If HIV infection is left untreated, immune system fails to & & & & \\
\hline & fight and this stage is called AIDS & & & & \\
\hline \multirow{2}{*}{$\begin{array}{l}\text { 4. HIV attacks and destroy the immune } \\
\text { system }\end{array}$} & Correct & 85 & $100 \%$ & & \\
\hline & False & - & - & & \\
\hline \multirow{2}{*}{$\begin{array}{l}\text { 5. I have a friend or relative infected with } \\
\text { HIV }\end{array}$} & Yes & 3 & $3.50 \%$ & & \\
\hline & No & 82 & $96.50 \%$ & & \\
\hline
\end{tabular}


Citation: Parcaoglu F, Gedik H (2017) HIV Knowledge and Awareness Status of the Medical Faculty Students in Romania: An Awareness Study. J Infect Dis Med 2: 111. doi: 10.4172/2576-1420.1000111

Page 3 of 5

\begin{tabular}{|c|c|c|c|c|}
\hline \multirow{9}{*}{ 6. If I know a person is infected with HIV } & I would never meet with that person again & 2 & $2.40 \%$ & \\
\hline & I would still keep my friendship or relationship with that person & 78 & $91.80 \%$ & \\
\hline & I would never eat the meal that person cooks & 6 & $7.10 \%$ & \\
\hline & I would never touch that person & 3 & $3.50 \%$ & \\
\hline & I would never use the items of that person & 22 & $25.90 \%$ & \\
\hline & I would never kiss that person & 15 & $17.60 \%$ & \\
\hline & I would never shake hands with that person & 1 & $1.20 \%$ & \\
\hline & I would tell that person's disease to everyone & 4 & $4.70 \%$ & \\
\hline & I would never share the same apartment & 13 & $15.30 \%$ & \\
\hline \multirow{5}{*}{ 7. I have information about HIV } & & - & - & 0.024 \\
\hline & not at all & & & \\
\hline & little & 12 & $14.10 \%$ & \\
\hline & enough & 59 & $69.40 \%$ & \\
\hline & too much & 14 & $16.50 \%$ & \\
\hline \multirow{2}{*}{$\begin{array}{l}\text { 8. Is birth control pill effective for HIV } \\
\text { prevention? }\end{array}$} & Correct & 65 & $76.50 \%$ & 0.0005 \\
\hline & FALSE & 20 & $23.50 \%$ & \\
\hline \multirow{5}{*}{$\begin{array}{l}\text { 9. If you have a sexual course with a } \\
\text { person whom you do not know before } \\
\text { or history of diseases, would you use } \\
\text { condom? }\end{array}$} & Depends on person & 11 & $12.90 \%$ & \\
\hline & Depends on my feelings & 2 & $2.40 \%$ & \\
\hline & No & 2 & $2.40 \%$ & \\
\hline & I always use condom & 70 & $82.40 \%$ & \\
\hline & Condom is too tiring & - & - & \\
\hline \multirow{2}{*}{$\begin{array}{l}\text { 10. Do you know the early signs or } \\
\text { symptoms of HIV infection? }\end{array}$} & Correct & 82 & $96.50 \%$ & \\
\hline & FALSE & 3 & $3.50 \%$ & \\
\hline \multirow{4}{*}{$\begin{array}{l}\text { 11. If your mother, or father, or wife, or } \\
\text { husband, or child acquired HIV after a } \\
\text { blood transfusion, how would you behave } \\
\text { him/her after you knew that situation? }\end{array}$} & I would not be in the same room & 1 & $1.20 \%$ & \\
\hline & I would never meet again & 1 & $1.20 \%$ & \\
\hline & I would meet but avoid close relationship & 9 & $10.60 \%$ & \\
\hline & I would keep my relation like in the past & 77 & $90.60 \%$ & \\
\hline \multirow{5}{*}{ 12. Do you know how HIV diagnosed is? } & Blood test & 83 & $97.60 \%$ & \\
\hline & Chest X-RAY & - & - & \\
\hline & $\mathrm{MRI} / \mathrm{CT}$ & 1 & $1.20 \%$ & \\
\hline & Visual Acuity Test & 1 & $1.20 \%$ & \\
\hline & Testing of hormone levels in blood & & & \\
\hline \multirow{3}{*}{ 13. If I have a question about HIV, } & I would ask to my friend & 1 & $1.20 \%$ & \\
\hline & I would ask to Goggle & 31 & $36.50 \%$ & \\
\hline & I would ask to a doctor & 53 & $64.20 \%$ & \\
\hline \multirow{4}{*}{$\begin{array}{l}\text { 14. If I have a HIV suspicious event or a } \\
\text { situation, }\end{array}$} & I would not mind, it cannot be transmitted to me & 1 & $1.20 \%$ & \\
\hline & I would commit suicide & 2 & $2.40 \%$ & \\
\hline & I would go to hospital & 76 & $89.40 \%$ & \\
\hline & I would search in Google & 6 & $7.10 \%$ & \\
\hline \multirow{7}{*}{$\begin{array}{l}\text { 15. Choose the wrong answer regarding } \\
\text { the stages of HIV infection }\end{array}$} & 3 stages; Acute, Chronic and AIDS & & & \\
\hline & Acute infection is the earliest stage, develops within $2-4$ weeks & & & \\
\hline & Chronic infection is the second asymptomatic stage & & & \\
\hline & AIDS is the last stage of the HIV infection & & & \\
\hline & Opportunistic infections occur in chronic stage & & & \\
\hline & Correct & 29 & $34.10 \%$ & \\
\hline & FALSE & 56 & $65.90 \%$ & \\
\hline \multirow{7}{*}{$\begin{array}{l}\text { 16. Choose the correct answer regarding } \\
\text { HIV }\end{array}$} & If a pregnant woman is infected with HIV, her baby will be infected with HIV too & & & \\
\hline & Showering after sexual intercourse prevents HIV transmission & & & \\
\hline & HIV can be transmitted by blood transfusion & & & \\
\hline & Every person who is infected with HIV has AIDS & & & \\
\hline & Female condoms are not effective in prevention of HIV transmission & & & \\
\hline & Correct & 71 & $83.50 \%$ & \\
\hline & FALSE & 14 & $16.50 \%$ & \\
\hline
\end{tabular}




\begin{tabular}{|c|c|c|c|c|}
\hline \multirow{8}{*}{$\begin{array}{l}\text { 17. Choose the correct answer regarding } \\
\text { HIV }\end{array}$} & & & & 0.001 \\
\hline & There is a vaccine for HIV prevention & & & \\
\hline & Antibiotics are first line treatment for HIV infection & & & \\
\hline & HIV is not transmitted by anal intercourse and oral intercourse & & & \\
\hline & Condoms are absolute protection against HIV & & & \\
\hline & HIV can be transmitted by getting a tattoo & & & \\
\hline & Correct & 52 & $61.20 \%$ & \\
\hline & FALSE & 33 & $38.80 \%$ & \\
\hline \multirow{7}{*}{$\begin{array}{l}\text { 18. Which one of those is not preventive } \\
\text { measure for HIV transmission? }\end{array}$} & Consistent and correct use of latex condom during sexual intercourse & & & \\
\hline & Avoiding multiple sexual partners & & & \\
\hline & Healthy diet and exercise & & & \\
\hline & Avoiding contact with people living with AIDS & & & \\
\hline & Avoiding use of others personal hygiene belongings & & & \\
\hline & Correct & 55 & $64.70 \%$ & \\
\hline & FALSE & 30 & $35.30 \%$ & \\
\hline \multirow{5}{*}{$\begin{array}{l}\text { 19. If you were informed to have HIV } \\
\text { infection, what would you do? }\end{array}$} & I would commit suicide & 1 & $1.20 \%$ & \\
\hline & I would never meet with any person & 1 & $1.20 \%$ & \\
\hline & I would never mind, I would keep my life living & 2 & $2.40 \%$ & \\
\hline & $\begin{array}{l}\text { I would receive HIV counseling from a HIV-specialist, and try to start } \\
\text { antiretroviral treatment as soon as possible }\end{array}$ & 3 & $3.60 \%$ & \\
\hline & I would transfer the virus other people not to inform them during sexual course & 78 & 91.8 & \\
\hline
\end{tabular}

Note: $P_{1}$ indicates the value obtained as a result of the statistical comparison of the responses between men and women. $P_{2}$ indicates the value obtained as a result of the statistical comparison of the responses by the grades of students in the faculty.

Table 1: Survey questions and response rates.

questions and to receive information about HIV. The Internet, which was the second preferred information source in our study, may be an important tool to inform the people and to increase their awareness about HIV/AIDS. The projects, including a direct counselling by an interview on the Internet or a communication with HIV related associations or non-governmental organizations as well as the websites to provide correct information about HIV/AIDS [14]. Since people frequently use the Internet to obtain information. Although all the students have revealed that they have information about HIV/AIDS, $30 \%$ of them did not know the difference between HIV and AIDS and several students did not know the all transmission routes of HIV exactly. The misconceptions about the transmission of HIV, such as hugging and kissing, sharing glasses with an infected person, mosquito bites, and sharing toilet seat, cause stigma against HIV positive people. Our findings were consistent with the findings of the other published studies in China, Turkey, India, and the USA [15-19]. Therefore, it is essential to introduce and provide the accurate information about the transmission routes of HIV to decrease the misconceptions, prejudice, and stigmatization [20].

Almost all of the students revealed that their attitudes towards people living with HIV/ AIDS were positive. However, approximately $20 \%$ of the students responded that they would not share an apartment, not use items of an infected person, and not kiss in related to the misconception of transmission routes, in. It should be emphasized in the seminaries about HIV/AIDS that HIV is not transmitted during a social relationship with HIV-positive people. There could be a social problem when HIV positive people are stigmatized in the society [21]. HIV related associations, foundations, and non-governmental organizations should organize informative meetings for the community to prevent the stigma.

There was a sufficient knowledge among the students about using condom as a way of prevention of sexually transmitted diseases, but some of the students revealed that they use condom depend on their feelings or partners. The rates of condom use are not at the desired level yet. The cognitive and emotional variables as well as the cultural aspects of perceptions were reported to be factors hampering the condom use $[22,23]$. Condom use should be encouraged by the advertisements and projects [24]. Only $76 \%$ of the students knew the ineffectiveness of birth control pills against HIV protection. That shows the gap in the knowledge about protection against HIV.

Even though most of the students responded that they would receive HIV counselling from an HIV specialist and try to start antiretroviral treatment as soon as possible, some students might either commit suicide or get isolated from the community, if they were diagnosed with HIV. HIV- related stigma, discrimination, prejudice, negative attitudes, and abuse were reported to be in $35 \%$ of countries and over $50 \%$ of people as the main reasons related to suicide and isolation from community [25]. Stigma, which causes poor treatment, detergency in educational and work settings, erosion of HIV-positive patients' rights, and psychological damage, is still a big problem through the world for HIV-positive patients. At this point, it should be pointed out that HIV is a chronic disease and it is possible to live a healthy and quality life for many years with antiretroviral therapy.

We found a significant difference between the knowledge level of the pre-clinical graders (grade 1 and 2) and the medical graders (grade from 3 to 6). It was reported that informative activities should be started in the early years of study to increase the knowledge [26,27]. Superficiality and insufficiency of information about HIV/AIDS in the curriculum of pre-clinical years in the medical schools can be related to our findings [28].

The limitation of this study was the insufficient number of students from each grade, as the distribution of students by grades was not 
Citation: Parcaoglu F, Gedik H (2017) HIV Knowledge and Awareness Status of the Medical Faculty Students in Romania: An Awareness Study. J Infect Dis Med 2: 111. doi: 10.4172/2576-1420.1000111

Page 5 of 5

similar. The study could have propounded more accurate results about the knowledge status of medical students, if the study was conducted with the sufficient number of students from each grade. The curriculum. The curriculum of the medical faculty and the presence of informative organizations about HIV were not evaluated to assess the effectiveness of them among the students in our study as well.

As a result, it is obvious that there are needed more healthinformative organizations targeting the young population especially at schools and universities about sexually transmitted diseases, especially HIV/AIDS - transmission routes, misconceptions about HIV, prevention measures, and the life expectancy after HIV acquirement. Those programs may raise the HIV awareness and be useful to change the behaviour change against HIV patients eliminating stigma. The dissemination and integration of HIV modules in the pre-medical faculties are needed to raise the information level about HIV and the social responsibility projects should be encouraged to raise the awareness of targeted social groups.

\section{Acknowledgement}

There is no conflict of interest.

\section{References}

1. Durack DT (1981) Opportunistic Infections and Kaposi's Sarcoma in Homosexual Men. N Engl J Med 305: 1465-1467.

2. Centers for Disease Control (1991) The HIVIAIDS epidemic: the first 10 years. MMWR Morb Mortal Wkly Rep 40: 357.

3. https://www.cdc.gov/hiv/basics/transmission.html

4. http://www.who.int/features/qa/71/en/

5. Hersh BS, Popovici F, Zolotusca L, Beldescu N, Oxtoby MJ, et al. (1991) The Epidemiology of HIV and AIDS in Romania. AIDS 5: 87-92.

6. Botescu A, Abagiu A, Mardarescu M, Ursan M (2012) HIVIAIDS among injecting drug users in Romania: Report of a recent outbreak and initial response policies. European Monitoring Centre on Drugs and Drug Addiction (EMCDDA), Lisbon.

7. Ministry of Health National Institute for Infectious Diseases (2013) Compartment for monitoring and evaluation of HIVIAIDS General data.

8. Ma Q, Ono-Kihara M, Cong L, Xu G, Zamani S, et al. (2006) Sexual behavior and awareness of Chinese university students in transition with implied risk of sexually transmitted diseases and HIV infection: A cross-sectional study. BMC Public Health 6: 232.

9. Anjum Q, Siddiqui H, Ahmed Y, Rizvi SR, Usman Y (2005) Knowledge of Students regarding Hepatitis and HIVIAIDS of a Private Medical University in Karachi. J Pak Med Assoc 55: 285-288.

10. DiClemente RJ, Forrest KA, Mickler S (1990) College students' knowledge and attitudes about AIDS and changes in HIV-preventive behaviors. AIDS Education and Prevention 2: 201-212.

11. Tavoosi A, Zaferani A, Enzevaei A, Tajik P, Ahmadinezhad Z (2004) Knowledge and attitude towards HIV/AIDS among Iranian students. BMC Public Health 4: 17 .

12. Bellingham K, Gillies $P$ (1993) Evaluation of an AIDS education programme for young adults. Journal of Epidemiology and Community Health 47: 134-138.

13. Lightfoot $M(2012)$ HIV prevention for adolescents: Where do we go from here? The American Psychologist 67: 661-671.
14. Hong Y, Li X, Mao R, Stanton B (2007) Internet Use among Chinese College Students: Implications for Sex Education and HIV Prevention. Cyberpsychol Behav 10: 161-169.

15. Wu Z, Pingping Y (2002) Research on knowledge, attitudes and practice about AIDS among university students in Fujian Province. Journal of Fujian Medical University 34: 194-196.

16. Albrektsson M, Alm L, Tan X, Andersson R (2009) HIVIAIDS Awareness, Attitudes and Risk Behavior Among University Students in Wuhan, China Open AIDS J 3: 55-62.

17. Ayranci U (2005) AIDS knowledge and attitudes in a Turkish population: an epidemiological study. BMC Public Health 5: 95.

18. Ganesan V, Chandrasekhar V, Raghavendra P, Rushender R (2016) A study on awareness of HIVIAIDS and attitude toward people living with HIVIAIDS among engineering college students of Nellore district, Andhra Pradesh, India. Int $J$ Community Med Public Health 3: 1219-1223.

19. Centers for Disease Control and Prevention (2012) Trends in HIV-Related Risk Behaviors among High School Students-United States, 1991-2011. MMWR Morb Mortal Wkly Rep 61: 556-560.

20. Biradar SM, Kamble VS, Reddy S (2016) Study to assess awareness about HIVIAIDS among medical students. Int J Community Med Public Health 3: 6264.

21. Haile Z, Kingori C, Darlington KA, Basta T, Chavan B (2017) HIV Risk Perception Among College Students at a University in the Midwest. Sexuality \& Culture 21: 62-73

22. Ballester-Arnal, R, Ruiz-Palomino E, Gil-Llario MD (2017) Structural Equation Modeling Test of an Integrated Model of Spanish Youth's Condom Use. AIDS Behav 21: 1407-1416.

23. Kirby DB, Laris BA, Rolleri LA (2007) Sex and HIV education programs: their impact on sexual behaviors of young people throughout the world. J Adolesc Health 40: 206-217.

24. Zhang H, Stanton B, Li X, Mao R, Sun Z, et al. (2004) Perceptions and attitudes regarding sex and condom use among Chinese college students: a qualitative study. AIDS Behav 8: 111-117.

25. World AIDS Day (2015) On the fast-track to end AIDS by 2030, Focus on location and population. Geneva: United Nations Programme on HIVIAIDS.

26. Samant Y, Mankeshwar R, Sankhe L, Parker DL (2006) HIV-Related Knowledge and Attitudes among First Year Medical Students in Mumbai, India Adolescents. International Electronic Journal of Health Education 9: 13-24.

27. Heads AM, Dickson JW, Asby AT (2017) Correlates of HIV Risk-taking Behaviors among African-American College Students: HIV Knowledge and Ethnic Identity. J Health Care Poor Underserved 28: 155-170.

28. Shankar R, Pandey S, Awasthi S, Rawat CMS (2011) Awareness of HIVIAIDS among first year medical undergraduates. Indian J Prev Soc Med 42: 168-172. 